\title{
Rare cause of a posterior mediastinal mass diagnosed at endobronchial ultrasound
}

\author{
Sarah Cullivan, ${ }^{1}$ Mohammed Ahmed, ${ }^{1}$ John Bruzzi, ${ }^{2}$ David Breen ${ }^{1}$
}

'Department of Respiratory Medicine, Galway University Hospitals, Galway, Ireland ${ }^{2}$ Radiology, Galway University Hospitals, Galway, Ireland

\section{Correspondence to}

Dr Sarah Cullivan,

sarah.cullivan@ucdconnect.ie

Accepted 7 December 2018

\section{DESCRIPTION}

A 67-year-old woman was referred for respiratory assessment with a history of chronic cough. There were no other associated symptoms and spirometry was normal. The initial chest radiograph was unremarkable, and a decision was made to further investigate with high-resolution CT of the chest. A posterior mediastinal mass was detected and a subsequent contrast CT of the thorax revealed
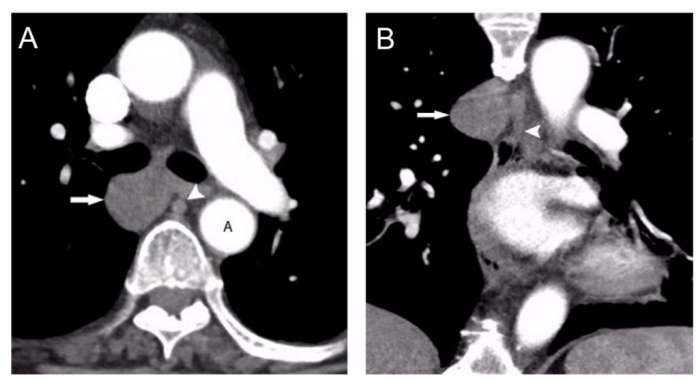

Figure $1 \quad(A, B)$ Axial $(A)$ and coronal $(B)$ contrastenhanced CT scans of the thorax demonstrate a $3 \mathrm{~cm}$ smoothly circumscribed hypodense soft-tissue mass in the posterior mediastinum (arrows) adjacent to the azygos vein (arrowheads). ( $A$, descending thoracic aorta).
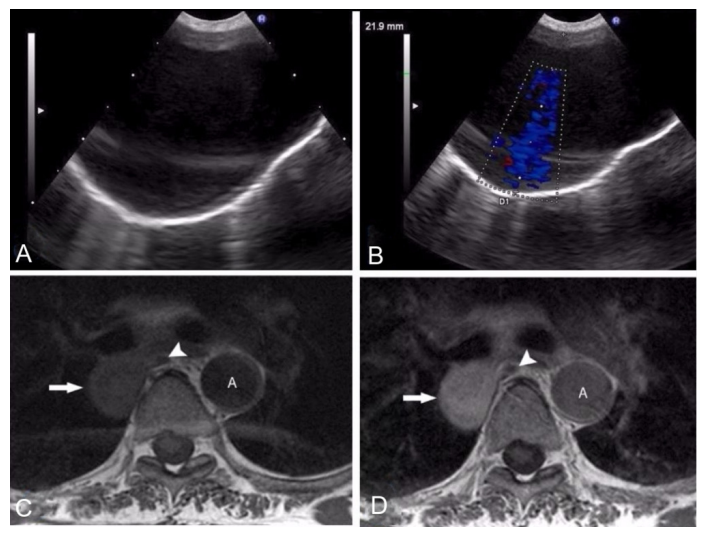

Figure 2 (A) Endobronchial ultrasound with curvilinear probe in contact with posterior wall of right main bronchus demonstrating the lesion of interest corresponding to the mediastinal mass on CT. Colour Doppler (B) confirms the vascular nature of the abnormality with anatomical location consistent with an azygos vein aneurysm. Axial T1-weighted sequences before (C) and after (D) Gadolinium enhancement demonstrate intense internal homogeneous enhancement. (Arrowhead, azygos vein; $A$, descending thoracic aorta). a $3 \mathrm{~cm}$ hypodense posterior mediastinal mass (figure 1). Endobronchial ultrasound (EBUS) was then performed using an ultrasound bronchoscope with a linear scanning transducer (Pentax EB-1970UK; Pentax Medical, Hamburg, Germany). EBUS revealed a mass lesion posterior to the right main bronchus with internal flow confirmed by Doppler (figure 2A,B). On further rotation of the scope along the posterior and lateral wall of the right main bronchus, the lesion was confirmed to communicate with the azygos vein. A diagnosis of an azygos vein aneurysm was made based on EBUS and anatomical features. This was confirmed by MRI scan with contrast (figure 2C,D).

An azygos vein aneurysm is rare. It is mostly detected incidentally on a chest radiograph and is often asymptomatic but can be complications can arise. ${ }^{1}$ It can mimic other more sinister causes of a mediastinal mass. This is the first case in the literature where the diagnosis of azygos vein aneurysm was made at EBUS highlighting the importance of this investigation in the diagnosis and detailed assessment of this condition.

Learning points

- The most common cause of mediastinal lesions is lymphadenopathy but other aetiologies need to be considered.

- Endobronchial ultrasound is the investigation of choice for assessment of mediastinal lesions close to the tracheobronchial tree.

- Azygos vein aneurysms are rare entities but should be considered in the differential diagnosis of posterior mediastinal masses before any needle sampling is attempted.

Contributors SC, MA, JB and DB were involved in manuscript preparation and submission. MA, DB and JB were involved in the patients clinical care. All authors have evaluated the case in detail and have approved the submission of the final manuscript.

Funding The authors have not declared a specific grant for this research from any funding agency in the public, commercial or not-for-profit sectors.

Competing interests None declared.

Patient consent Obtained.

Provenance and peer review Not commissioned; externally peer reviewed.

\section{REFERENCE}

1 Ko SF, Huang CC, Lin JW, et al. Imaging features and outcomes in 10 cases of idiopathic azygos vein aneurysm. Ann Thorac Surg 2014;97:873-8. 
Copyright 2018 BMJ Publishing Group. All rights reserved. For permission to reuse any of this content visit https://www.bmj.com/company/products-services/rights-and-licensing/permissions/

BMJ Case Report Fellows may re-use this article for personal use and teaching without any further permission.

Become a Fellow of BMJ Case Reports today and you can:

- Submit as many cases as you like

- Enjoy fast sympathetic peer review and rapid publication of accepted articles

Access all the published articles

- Re-use any of the published material for personal use and teaching without further permission

For information on Institutional Fellowships contact consortiasales@bmjgroup.com

Visit casereports.bmj.com for more articles like this and to become a Fellow 